Marquette University

e-Publications@Marquette

$1-1-2015$

Law Enforcement as Legal Mobilization: Reforming the Pharmaceutical Industry Through Government Litigation

Paul Nolette

Marquette University, paul.nolette@marquette.edu

This is the peer reviewed version of the following article: "Law Enforcement as Legal Mobilization: Reforming the Pharmaceutical Industry Through Government Litigation," Law \& Social Inquiry, Vol. 40, No. 1 (Winter 2015): 123-151, which has been published in final form here: DOI. (c) 2015 Wiley. Used with permission. This article may be used for non-commercial purposes in accordance With Wiley Terms and Conditions for self-archiving. 
NOT THE PUBLISHED VERSION; this is the author's final, peer-reviewed manuscript. The published version may be accessed by following the link in the citation at the bottom of the page.

\title{
Law Enforcement as Legal Mobilization: Reforming the Pharmaceutical Industry through Government Litigation
}

\author{
Paul Nolette \\ Department of Political Science, Marquette University \\ Milwaukee, WI
}

\begin{abstract}
Scholars of legal mobilization have long explored how litigation is used as a resource for social and political change. While most studies focus on the actions of private groups, this article considers law enforcement as a form of legal mobilization. Employing a case study of recent pharmaceutical litigation, this article examines how prosecutors have mobilized the law to reshape corporate responsibilities in the prescription drug industry. Prosecutors' litigation campaigns have forced changes in organizational practices, expanded the scope of the conflict over pharmaceutical industry actions, and established new legal norms that have spread throughout the political system. This form of prosecutor-led legal mobilization has occurred in other contexts as well, including gun control and mortgage lending. In addition to indicating how lawyers within the state can engage in a form of cause lawyering, the government litigation explored in this article illustrates both the instrumental and constitutive power of the law.
\end{abstract}


NOT THE PUBLISHED VERSION; this is the author's final, peer-reviewed manuscript. The published version may be accessed by following the link in the citation at the bottom of the page.

\section{Introduction}

The mobilization of law for social and political reform has long been a central topic in the study of law and society (Zemans 1983; Epp 1998; Albiston 1999; Barnes \& Burke 2012). Studies of legal mobilization have typically focused on how private individuals and groups, such as civil rights and environmental organizations, use legal resources against the state. This focus reflects the "bottom-up" approach to the study of law employed by numerous legal mobilization studies (McCann 1994; Ewick \& Silbey 1998; Paris 2010). While these studies often adopt a narrative of private groups against the state, however, powerful legal actors within the state have also mobilized the law in ways mirroring the efforts of social movements. These efforts have transformed existing political arrangements and reshaped corporate practices in order to address policy demands left unmet by other parts of the state.

In this article, I consider how government prosecutors, especially state attorneys general and their federal counterparts in the U.S. Department of Justice, have employed litigation as a form of legal mobilization. My examination centers on a substantively important, though little studied, recent litigation campaign: government litigation against the pharmaceutical industry. Over several years, state and federal prosecutors succeeded in re-framing widely accepted pharmaceutical industry practices into what policymakers and the public now perceive as a massive fraudulent conspiracy operated by drug companies. This effort, arising in an era of growing concern about health care costs, was a reaction to congressional unwillingness to change the way the government paid for prescription drugs through Medicare and Medicaid. By using innovative legal arguments, prosecutors employed the law to achieve significant nationwide changes throughout the multi-billion dollar pharmaceutical industry. While this article focuses mainly on pharmaceutical litigation, legal mobilization by government prosecutors is a phenomenon that has appeared in several other contemporary contexts. Near the conclusion, I draw attention to two additional cases, gun control and reform of mortgage lending practices, which have followed patterns similar to that of the pharmaceutical litigation.

Government-led litigation is of interest to socio-legal scholars for several reasons. For one, this study suggests that law enforcement can be an important form of legal mobilization. Apart from the role of 
public prosecutors in the tobacco litigation of the 1990s, which spurred several important studies (Mather 1998; Derthick 2001; McCann, Haltom \& Fisher 2013), scholars have generally overlooked government litigation as a political reform strategy. This is largely because mobilization studies tend to focus on non-state actors and because government litigation campaigns have unfolded over long periods rather than being resolved in landmark court cases. By tracing a sustained reform-oriented litigation campaign by public prosecutors, my article contributes to recent scholarship examining the role of activist government lawyers (Berenson 2009; NeJaime 2012) and responds to calls that greater attention be paid to complex litigation and mobilization by powerful actors (McCann 2008:535).

The activity examined in this article also illustrates that the distinction between "outsider" groups seeking to reform institutions and the "insiders" residing within those organizations is often blurred. While previous law and society scholarship has emphasized this point (Katzenstein 1998), most studies of "institutional insiders" who attempt to reform their own organizations focus on non-state insiders such as those within corporations (Raeburn 2004) and schools (Binder 2002). Meanwhile, the relationship between government actors and outsider activism is typically discussed in terms of "elite alliances" or elite support (McCann 1994). "The state" typically appears as a monolithic actor that reacts with varying levels of support or resistance to pressure from outsider movements. This article suggests, however, that the role of government actors in the process of legal mobilization can stretch beyond simply providing "support" for outsider movements by initiating challenges to other parts of the state to which they belong. These challenges often enlist other allies within the state especially federal agencies - but do so in the context of challenging existing government policy. This helps illustrate that the role of "the state" in processes of legal mobilization is more complex and differentiated than often portrayed.

Further, government-driven legal mobilization illustrates the effectiveness of law-based reform, in contrast to scholarly skeptics (Rosenberg 1991, 2008). Prosecutors' use of the law has altered the political status quo in numerous direct and indirect ways, significantly affecting the practices of several of America's largest industries. Prosecutors have used threats of lawsuits to reach settlements with industry defendants that create regulatory requirements not otherwise

Law \& Social Inquiry, Vol 40, No. 1 (Winter 2015): pg. 123-151. DOI. This article is (C) Wiley and permission has been granted for this version to appear in e-Publications@Marquette. Wiley does not grant permission for this article to be further copied/distributed or hosted elsewhere without the express permission from Wiley. 
required under existing law. This litigation has also served to alter the political status quo in more subtle ways, including reshaping existing legal norms and creating new avenues for coordinated legal activism. Finally, this study forges a link between interbranch studies of law and courts and legal mobilization scholarship. Both of these areas share much common ground despite largely operating in two separate scholarly spheres. An increasing number of law and courts scholars have challenged the tendency of legal studies to have an excessively narrow focus on the formal decisions of courts, especially the U.S. Supreme Court, without contextualizing these decisions in the broader landscape of institutional activity. Barnes, for example, highlights the importance of "microinstitutional analysis" that seeks to understand how continuously unfolding legal processes operate simultaneously across multiple political institutions (2007:33). This interbranch approach helps illustrate how major changes in law and public policy result from subtle institutional interactions over time. Given that law and society scholarship has long recognized that law's importance stretches well beyond decisions of the Supreme Court, the interbranch perspective and law and society scholarship have much in common. The emergence of law enforcement as a form of legal mobilization offers much of interest to scholars in both camps, and responds to calls for more linkages between scholarship studying complex organizations and studies focusing on social movements (Davis et al. 2005).

\section{Law Enforcement as Legal Mobilization}

Scholars have generally examined legal mobilization by adopting either an instrumental perspective emphasizing how law directly influences society "by imposing external sanctions and inducements" or a constitutive perspective that draws attention to the role of law in "shaping internal meanings and creating new statuses" (Mather 1998:900; Sarat \& Kearns 1993; McCann 1994; McCann 2008). These perspectives need not be mutually exclusive, however. Particularly since the late 1990s, government prosecutors have employed criminal and civil lawsuits as a way to not simply "enforce the law" but to change it in ways that straddle the line between these instrumental and constitutive perspectives.

Law \& Social Inquiry, Vol 40, No. 1 (Winter 2015): pg. 123-151. DOI. This article is @ Wiley and permission has been granted for this version to appear in e-Publications@Marquette. Wiley does not grant permission for this article to be further copied/distributed or hosted elsewhere without the express permission from Wiley. 
The best known example of this dynamic occurred in the late 1990s, when state attorneys general (AGs) across the nation led a litigation campaign against tobacco companies. This litigation resulted in a \$206 billion Master Settlement Agreement (MSA), which to date remains the largest civil settlement in American history. The MSA, which followed the failure of comprehensive tobacco regulation in Congress, established a host of new tobacco advertising regulations, industry lobbying restrictions, and new de facto taxes on cigarettes (Derthick 2001). Mather's study of this litigation revealed the ways in which it had both direct and indirect effects by serving as a method of agenda setting and issue framing (Mather 1998). McCann, Haltom, and Fisher likewise examine the instrumental and constitutive dimensions of tobacco litigation in their study of how tobacco firms were "criminalized" over time, though with the suggestion that the process they trace may be limited to the peculiar politics of tobacco (2013:30).

Since the tobacco litigation, however, government attorneys have used lawsuits and legal settlements across a wide range of industries - including the multi-billion dollar pharmaceutical industry with the goal of fundamentally changing the way that these corporate organizations operate. Much like the tobacco litigation, this activity has involved one part of the state (government prosecutors) attempting to employ the law in order to change the policy status quo supported by another part of the state (particularly the policy choices of Congress). I suggest that they have done so in three main ways.

First, prosecutors' pharmaceutical litigation had the direct effect of forcing organizational change by using out-of-court settlements as a mechanism for imposing external sanctions on corporate organizations. This approach is consistent with the longstanding recognition of the importance of "bargaining in the shadow of the law" (Mnookin \& Kornhauser 1979). The prospect of avoiding the substantial costs of active litigation explains why disputants often bargain in the shadow of the law rather than relying upon official legal actors to make decisions binding on both parties (McCann 2006:514). Recent government litigation illustrates this process at work. Prosecutors have used threats of additional litigation costs and bad publicity to persuade companies to enter settlements that fundamentally alter their corporate obligations. Additionally, these settlements have served as a way to "legalize accountability" in targeted industries. Epp explains how activists mobilized the law to 
force local government bureaucracies to adopt new written rules, employee training programs, and new structures of managerial oversight in order to foster greater institutional compliance with emerging legal norms (2009). Government-led settlements between government litigators and corporations have included similar mechanisms, with the aim of reforming the internal operations of corporate defendants as a means to ensure compliance with the prosecutors' newly created legal requirements.

Second, prosecutors' legal mobilization campaigns have served as a vehicle to expand the scope of the conflict over corporate activities by attracting other parties to the conflict over pharmaceutical prices. E.E. Schattschneider suggested that the "central political fact in a free society is the tremendous contagiousness of conflict" (1960:2). How a particular conflict is resolved, he argued, will depend largely on the breadth of its scope. Political disputes that draw in additional participants and adequately "socialize" conflict are more likely to have an impact on the existing political status quo (ibid: 7). Expanding the scope of the conflict is particularly important for those on the losing side of a conflict; "it is the loser who calls in outside help" (ibid:16). Several government litigation campaigns have sought to alter the political status quo after failed attempts to achieve these goals in other, more typical, policy-making venues. After initiating a law-based alternative method of policy change, prosecutors sought to expand the scope of the conflict by allying with several other actors. This has included other actors within the state, particularly bureaucratic agencies, as well as external actors such as advocacy groups and class-action attorneys.

Third, this government-led litigation has had the constitutive effect of establishing new legal norms transforming existing understandings of key concepts such as "fraud." Scholars of social movements have noted the importance of "discursive opportunity structures" to the success of efforts for political change. For particular claims to gain public visibility, resonate with policymakers, and gain legitimacy, groups must frame their claims in a way that connects with widely accepted beliefs in society (Ferree, et al. 2002). Effective framing choices designed to challenge the status quo "must take into account and be shaped by the specific features of the complicated landscape on which they compete" (ibid.: 71). Claims that do not link with available discursive opportunities may face significant constraints 
as compared to those framed in more "acceptable" ways. In several of their litigation campaigns, prosecutors have framed the underlying changes to the status quo as necessary to prevent "fraud" and "lawbreaking," thus adopting frames that made success more likely than previous efforts to achieve reform. These characterizations resonated across the political spectrum and helped shift the conflict away from polarized debates operating under frames less amenable to altering the status quo.

The rise of government law enforcement to force organizational change, expand the scope of conflict, and establish new legal norms has occurred parallel to two broader developments in contemporary American politics: increasing congressional gridlock and the attack on private litigation. Divided government and increased political polarization have made traditional policy making more difficult, leading policy advocates to resort to "unorthodox lawmaking" (Sinclair 2011). Though Sinclair uses this phrase to discuss the development of new legislative procedures, the notion of unorthodox lawmaking also captures the turn to alternative methods of policy change, including the courts and legal mobilization. At the same time that policy advocates have turned to these other ways to achieve policymaking, however, the role of private litigation in American society has become more controversial. Concerns about an alleged "litigation explosion" in America prompted Congress and the federal courts to curtail opportunities for private litigators to bring lawsuits against corporations (Class Action Fairness Act of 2005; Wal-Mart v. Dukes; AT\&T Mobility v. Concepcion).

As achieving policy change through typical policy-making institutions has become more difficult and private litigators have faced more roadblocks in their efforts to employ the law, government prosecutors have become a focal point for efforts to mobilize the law to alter the political status quo. I now turn to one of the most prominent of these efforts: reform of pharmaceutical industry practices through law enforcement. ${ }^{1}$

\section{The Politics of Pharmaceuticals}

The effort by government prosecutors to mobilize the law as an instrument of pharmaceutical industry reform has received surprisingly little attention among scholars of law and politics despite the salience

Law \& Social Inquiry, Vol 40, No. 1 (Winter 2015): pg. 123-151. DOI. This article is @ Wiley and permission has been granted for this version to appear in e-Publications@Marquette. Wiley does not grant permission for this article to be further copied/distributed or hosted elsewhere without the express permission from Wiley. 
and contentiousness of health care policy in contemporary American politics. In 2010, total health care spending represented about 18 percent of the United States' entire gross domestic product, up from 13.8 percent as recently as 2000 (Kaiser Family Foundation 2012). Expenditures on prescription drugs, which reached $\$ 307$ billion nationally in 2010 (Gatyas 2011), have been a significant part of this overall spending. Americans have faced some of the highest prescription drug prices in the world for years, with pharmaceutical costs rising much faster than general health care inflation (Danzon and Furukawa 2008).

Throughout the late 1980s and into the 1990s, lawmakers and activists began focusing on allegedly unscrupulous drug industry practices as a driver of high pharmaceutical costs. For example, Representative Henry Waxman (D-CA), one of the industry's biggest critics, argued early in the 1990s that "unless the industry can provide an adequate explanation for these price hikes, one can only conclude that what is going on is greed on a massive scale" (Rovner 1992). Groups such as the AARP emphasized the impact of pharmaceutical company practices on the pocketbooks of the poor and elderly (Pear 2002). Other advocacy organizations argued that rapidly rising health care costs violated basic tenets of justice and fairness. Community Catalyst, founded in 1997 as the "voice for consumers in health care reform," cited rising drug costs as a major obstacle to its goal of guaranteed access to high quality, affordable health care for all (Community Catalyst).

For years, advocacy groups and their legislative allies sought to combat alleged drug company "greed" through legislation aimed at controlling prescription drug prices. Several proposals sought to eliminate tax subsidies for drug companies and provide a combination of carrots and sticks to ensure that increases in drug prices remained in line with overall inflation (Medication Price Control Act of 1991; Prescription Drug Cost Containment Act of 1992). These efforts appeared to receive a major boost with the election of President Bill Clinton, who in 1993 announced a plan that would expand drug coverage provided under government health care programs while also attempting to control pharmaceutical inflation. Among other ideas, Clinton proposed a new National Health Board tasked with investigating "unreasonable" drug prices. Borrowing a popular idea from industry critics, Clinton also proposed allowing the Secretary of 
Health and Human Services (HHS) to negotiate with pharmaceutical companies over drug prices paid for by the government (Freudenheim 1993).

Despite a two-year window in which Democrats enjoyed unified control of Congress and the presidency, however, these legislative attempts to expand government regulation over the pharmaceutical industry failed. Representatives from drug companies denounced Clinton's pharmaceutical proposals as an attempt to achieve price controls on prescription drugs that would "slow down or eliminate the volume of research" on new drug innovation (ibid). When the 1994 elections gave Republicans control of both houses of Congress, the prospects for pharmaceutical pricing reform looked bleak. Clinton's push for reform had failed even with a Democratic Congress, and it was unlikely that the new conservative majority would pursue strict government regulation of drug companies. Advocates for lower drug prices continued pursuing other ways to control drug costs, such as allowing the re-importation of prescription drugs from Canada, where pharmaceutical prices are lower because of direct government price controls (Prescription Drug Parity Act of 1999). The efforts, like those before them, foundered on concerns that government intervention would damage private sector innovation.

\section{Efforts to Reform the "Average Wholesale Price" System}

Amidst these failed legislative efforts, an alternative route to reform pharmaceutical industry practices involved changing how government health care programs pay for prescription drug coverage. At the center of these efforts were attempted reforms of a drug pricing system known as "Average Wholesale Price" (AWP). Since shortly after the creation of Medicare and Medicaid in 1965, AWP has served as the pricing benchmark the government uses to pay for drugs covered by these programs. Pharmaceutical companies do not receive government reimbursements directly under Medicare and Medicaid, but instead make money by selling pharmaceuticals to health care providers. These providers include pharmacies that dispense drugs to patients, as well as doctors and hospitals that purchase physician-administered drugs directly from pharmaceutical companies for use at doctors' offices or in the hospital outpatient setting. The government then

Law \& Social Inquiry, Vol 40, No. 1 (Winter 2015): pg. 123-151. DOI. This article is C Wiley and permission has been granted for this version to appear in e-Publications@Marquette. Wiley does not grant permission for this article to be further copied/distributed or hosted elsewhere without the express permission from Wiley. 
reimburses the providers according to the AWP for each prescribed drug.

In theory, the AWP is supposed to reflect the average price providers pay drug companies for prescription drugs. The AWP, however, has no statutory definition. Governments receive AWP information for drugs from private commercial publishers of drug pricing data, the most prominent being First DataBank. These commercial publishers in turn receive the AWP pricing information directly from manufacturers themselves (Gencarelli 2002:3). Figure 1 illustrates the crucial role of AWP in government reimbursements for prescription drug coverage.

[Figure 1 about here]

The problem is that the AWP, despite its name, is not an "average" price at all. Drug companies have discretion to set the AWPs for their products themselves. The AWPs are often considerably higher than the actual amount providers pay for drugs because the AWPs do not reflect the many discounts drug companies offer providers as an incentive to purchase their products. In this respect, the AWP is similar to the "sticker price" for vehicles in the automobile industry. The difference between this AWP sticker price and the actual price providers pay for the drugs is known as the "spread." Because the government reimburses providers based on the AWPs - and not the actual amount drug companies charge providers for the drugs providers can make extra money by prescribing drugs with high spreads. For example, a manufacturer might sell a physicianadministered drug to a doctor for 30 cents a dose, but set the AWP at $\$ 1$ a dose. The government would then reimburse the doctor $\$ 1$ a dose despite the doctor's actual cost being only 30 cents. The physician thus pockets a profit of 70 cents for each dose (Pear 2001). Drug companies, in turn, have the incentive to inflate their reported AWPs so they can offer health care providers spreads higher than those available for competing products.

The government has long been aware that these incentives could drive up drug costs. As early as 1968, officials had noted that increasing the spread between actual drug costs and the reported AWP could be a way for drug companies to "maneuver against competing products." As concerns about rising health care costs rose in the 
1990s, President Clinton noted the problems with the flawed, but legal, AWP system. In a 1997 address calling for additional efforts to reduce health care costs, Clinton described the AWP system as an example of types of "waste and abuse" that "aren't even illegal [because] they're just embedded in the practices of the system" (Spears \& Pullman 2002:73). For years, the difference between AWP and the actual market prices for drugs led pharmaceutical industry observers to refer to AWP as "Ain't What's Paid" (Kalb, Bass, and Fabrikant 2001).

This issue was important to many other groups beyond government officials. While AWP served as the main pricing benchmark for government reimbursements, it also was the price private insurers and health care plans used to determine reimbursements for prescription drugs. This included Blue Cross/Blue Shield insurance associations, union health care plans, and self-insured employers across the country (Gencarelli 2002:3). These groups, like the government, had paid billions of dollars in prescription drug reimbursements based upon AWP.

Despite the many concerns raised about AWP, Congress continued the use of this manufacturer-reported benchmark. This was largely because of lobbying efforts by physicians who argued that it would be impossible for them to stay in business and serve Medicare and Medicaid recipients without benefiting from the spread created by the AWP (Carter 2002:44). According to these health care providers, the spread helped to make up for losses due to inadequate government payments for other services they provided under Medicare and Medicaid. Further, the pharmacy industry claimed that the spread enabled pharmacies to cover their costs in states where the stateprovided dispensing fees for Medicaid-covered prescriptions were inadequate to cover the pharmacies' actual dispensing costs (Gencarelli 2002:7).

Despite the convoluted nature of the AWP system, these arguments convinced Congress to maintain AWP as the pricing benchmark in government health care programs even in the face of the Clinton Administration's significant push to change the system. In his 1998 budget proposal, Clinton proposed eliminating AWP and replacing it with a formula directly related to actual costs paid by providers. Congress rejected this proposal, instead making much less drastic changes to the drug reimbursement formula in the Balanced Budget Act of 1997. The Administration subsequently fought for larger

Law \& Social Inquiry, Vol 40, No. 1 (Winter 2015): pg. 123-151. DOI. This article is (C) Wiley and permission has been granted for this version to appear in e-Publications@Marquette. Wiley does not grant permission for this article to be further copied/distributed or hosted elsewhere without the express permission from Wiley. 
tweaks to the AWP payment system in both 1999 and 2000, but neither of these proposals gained traction in Congress.

\section{From Legislative Efforts to Legal Mobilization}

Amidst these numerous failed legislative attempts to control prescription drug costs, the locus of activity shifted from Congress to the courtroom. The shift was similar to what was occurring in the context of tobacco policy, where failures to achieve industry regulation in Congress spurred the nation's AGs to work together on what would become the Master Settlement Agreement. At the same time that President Clinton was highlighting the potential of AWP in driving higher drugs costs, federal and state prosecutors began collecting information from leading pharmaceutical firms concerning their prescription drug pricing strategies (Alpert 1997). This investigation gradually blossomed into a full-scale litigation campaign in which prosecutors, as with the tobacco litigation, made no secret that they were attempting to alter practices in the pharmaceutical industry on a national scale. As one member of the Florida AG's office put it, "the goal is nothing less than changing the way the industry does business" (Guiden 2001).

\section{Forcing Organizational Change within Big Pharma}

During their initial investigations, state and federal prosecutors began characterizing as "fraudulent" the way in which drug companies marketed the spread between AWP and actual costs to provide incentives to providers for prescribing their products. Soon after, they sought a settlement with a major drug manufacturer in the hope that it would set a precedent for other companies to move away from the use of AWP (Cloud \& McGinley 2000). Central to the government strategy was an innovative interpretation of the False Claims Act ("FCA"), a Civil War-era statute that originally aimed to crack down on "rampant fraud" among defense contractors doing business with the Union army (Krause 2004:65). According to the prosecutors, marketing the spread represented illegal fraud under the FCA.

The suggestion that the AWP system, which even President Clinton had acknowledged was legal, was actually fraudulent came as a surprise to the pharmaceutical industry. Industry members observed

Law \& Social Inquiry, Vol 40, No. 1 (Winter 2015): pg. 123-151. DOI. This article is @ Wiley and permission has been granted for this version to appear in e-Publications@Marquette. Wiley does not grant permission for this article to be further copied/distributed or hosted elsewhere without the express permission from Wiley. 
that the government had known for years that marketing the spread was an accepted industry practice and yet explicitly kept AWP as part of the government reimbursement system. Nevertheless, the prospect of FCA liability was particularly disturbing for pharmaceutical firms, since every filled Medicare or Medicaid prescription could be a "false claim" subject to treble damages and the maximum penalty under the statute. These penalties could quickly add up to create potential exposure to these firms running into hundreds of millions of dollars. Additionally, if a company was found guilty of any criminal violations involved in a potential suit, the company could be excluded from Medicare and other federal health care programs. Given the share of the overall pharmaceutical market that government programs represent, this penalty is akin to a corporate "death sentence" (Zalesky 2006). Under these conditions, drug companies realized that litigating government claims all the way to a jury verdict would be risky and potentially fatal.

The FCA cast a long shadow over the bargaining between prosecutors and leading members of the industry. In January 2001, the negotiating leverage prosecutors derived from the FCA paid off. Since May of the previous year, prosecutors had been in talks with Bayer Pharmaceuticals to resolve allegations that Bayer fraudulently marketed the spread of its hemophilia and AIDS drugs. Under pressure from threatened litigation and unwilling to risk a corporate "death sentence" if found liable under the FCA, Bayer settled the governments' allegations. In addition to requiring Bayer to pay $\$ 14$ million, the settlement required the company to report a new pricing benchmark that prosecutors hoped would become an alternative to AWP. This new pricing benchmark, called the "Average Sales Price" (ASP), sought to reflect actual prices providers paid for prescription drugs including all discounts, rebates, and other benefits tied to the purchase of the drug (Bayer Corporate Integrity Agreement 2001:1115). Because the ASP, unlike the AWP, was a defined term and set by actual market prices rather than by the manufacturer, this was intended to reduce price "manipulation" by the pharmaceutical industry.

In addition to establishing a new pricing system that prosecutors hoped would serve as an alternative to AWP, the Bayer settlement was also crucial for the way it attempted to legalize accountability throughout the organization. The settlement required

Law \& Social Inquiry, Vol 40, No. 1 (Winter 2015): pg. 123-151. DOI. This article is @ Wiley and permission has been granted for this version to appear in e-Publications@Marquette. Wiley does not grant permission for this article to be further copied/distributed or hosted elsewhere without the express permission from Wiley. 
the company to appoint an internal compliance officer and create a compliance committee tasked with monitoring Bayer's day-to-day adherence to the settlement's regulatory terms. The committee was required to create new written codes of conduct detailing the internal procedures Bayer would take to comply with the agreement (Bayer Corporate Integrity Agreement 2001:4). In addition, the settlement required specific training and educational programs for employees to ensure compliance. While the settlement placed responsibility of implementing these provisions on the company, all of the company's actions were subject to enhanced oversight by the federal government (ibid: 29).

The government prosecutors viewed the Bayer settlement as a watershed agreement that could prompt the replacement of the existing AWP system with the "more accurate" ASP system. New York Attorney General Eliot Spitzer characterized the settlement as "a significant victory.... [that] sends a strong message to other pharmaceutical manufacturers and health care providers that we will not allow them to enrich themselves at the expense of taxpayers and those most in need" (Pear 2001). This "strong message" resonated across the industry, as Bayer became the first domino to fall in the government prosecutors' strategy to attack the AWP reimbursement system.

Following the Bayer settlement was an even more significant agreement later in 2001, which involved TAP Pharmaceuticals and its cancer drug, Lupron. As with the Bayer case, government prosecutors claimed that TAP's marketing the spread represented illegal fraud under the FCA. TAP disputed these allegations, but the threat of a corporate "death sentence" helped federal and state prosecutors to achieve a $\$ 875$ million settlement with TAP, the largest health care fraud settlement in history to that time (Department of Justice 2001). Much like the Bayer settlement, the TAP agreement sought to legalize accountability by forcing the creation of internal oversight provisions. It also required TAP to enter into an agreement with HHS requiring government oversight of the company's marketing and sales practices for seven years, the first settlement to require this sort of scrutiny. Perhaps most importantly, the settlement required TAP to report the ASP for each of its drugs on a quarterly basis, similar to the provision the prosecutors had won in the Bayer settlement. The settlement permitted the Center for Medicare and Medicaid Services (CMS), an 
agency within HHS, to rely upon this ASP data in setting reimbursement rates for TAP's products under Medicare. It also allowed state Medicaid programs to use ASPs to set their own reimbursements rates (TAP Corporate Integrity Agreement 2001:1011).

The prosecutors' bargaining in the shadow of the law proved to be a powerful method of policy-making for two important reasons. First, unlike policies created through typical policy making or regulatory processes, the new corporate responsibilities couched in these agreements were largely immune from judicial review. This was a particularly important benefit given the uncertain legal ground upon which the threatened Bayer and TAP lawsuits rested. The contention that AWP was "fraudulent" faced a number of legal problems, including the fact that health care providers, and not pharmaceutical firms, were the direct beneficiaries of the AWP spread. The government had also long known that AWP really meant "Ain't What's Paid" - and even explicitly maintained AWP as a way to ensure that physicians and other providers were adequately compensated by the Medicare and Medicaid programs. However, by lodging their regulation of the pharmaceutical industry in out-of-court settlements, prosecutors simultaneously leveraged judicial power to force new regulations while insulating these regulations from judicial review.

Second, these settlements were largely self-implementing since they did not rely upon third parties - courts and judges - to enforce organizational change. Because new corporate responsibilities were lodged in an "agreement," it was easier to obtain immediate buy-in on the part of the regulated industry. Enforcement then proceeded along two tracks: legalized accountability through instituting internal mechanisms of compliance along with increased oversight by the government parties to the agreement. These enforcement mechanisms helped sidestep the oft-cited problem that courts lack enforcement capabilities necessary to effectuate widespread change because they have neither the power of sword nor the purse (Rosenberg 1991, 2008).

\section{Expanding the Scope of AWP Litigation}

Critical to the government litigators' efforts to change organizational culture and policy on a national scale was their ability to

Law \& Social Inquiry, Vol 40, No. 1 (Winter 2015): pg. 123-151. DOI. This article is @ Wiley and permission has been granted for this version to appear in e-Publications@Marquette. Wiley does not grant permission for this article to be further copied/distributed or hosted elsewhere without the express permission from Wiley. 
draw in additional participants to the conflict over pharmaceutical prices. Prosecutors stood at the center of an emerging fight about drug industry practices, providing an arena for the socialization of conflict pertaining to a once obscure issue seemingly of interest mainly to health care providers. This role was particularly important given that advocates for industry reform were losing in traditional policy-making venues. Coming on the heels of failed legislative attempts to reform drug pricing practices, the watershed Bayer and TAP settlements served as a major "wake up call" to the industry (Pharmaceutical Law \& Industry Report 2001) and as a prototype for a subsequent wave of lawsuits by state-level public prosecutors as well as private classaction litigators.

\section{The Expansion of State Litigation}

Following the Bayer and TAP settlements, AGs from across the nation pursued their own state-level AWP claims against drug companies. Texas AG John Cornyn filed the first individual state AWP lawsuit in the fall of 2000 , alleging that three pharmaceutical firms had inflated the AWP for asthma inhalants and marketed the spread to pharmacists (Appleby 2000). Several other AGs soon followed with increasingly expansive claims of their own. For example, Nevada AG Frankie Sue Del Papa's lawsuit in early 2002 not only named a dozen defendants but also contained a variety of Medicaid fraud, antitrust, and consumer protection claims (Elfin 2002). Del Papa's complaint also repeatedly referred to the pharmaceutical companies' behavior as part of a "racketeering enterprise" and an "AWP Scheme," an attempt to coin negative labels for pricing behavior that had for decades been part of the government's reimbursement system. Del Papa noted that the breadth of her complaint, which also sought a redefinition of AWP, "has nationwide applications because of its similarities to the historic tobacco litigation in which the states eventually recovered billions of dollars" (ibid).

The quantity of litigation expanded from these early state efforts, both in terms of the number of states involved in bringing lawsuits as well as the number of defendants targeted by the lawsuits. Table 1 indicates the progression of these state lawsuits over time. ${ }^{2}$

[Table 1 about here]

Law \& Social Inquiry, Vol 40, No. 1 (Winter 2015): pg. 123-151. DOI. This article is @ Wiley and permission has been granted for this version to appear in e-Publications@Marquette. Wiley does not grant permission for this article to be further copied/distributed or hosted elsewhere without the express permission from Wiley. 
NOT THE PUBLISHED VERSION; this is the author's final, peer-reviewed manuscript. The published version may be accessed by following the link in the citation at the bottom of the page.

State prosecutors collaborated closely on these cases. The key organizational mechanism was the Pharmaceutical Task Force established in 2002 under the auspices of the National Association of Attorneys General. The goal of this Task Force was to encourage communication and collaboration among the states, federal enforcement agencies, and the private bar. In addition to serving as an information clearinghouse for AGs bringing their own lawsuits, the Task Force served as an umbrella under which several multistate lawsuits against the pharmaceutical industry proceeded (Cutler 2003).

\section{Collaborations with Federal Agencies, Private Litigators, and Advocacy Groups}

Throughout the expanding AWP litigation campaign, state and federal prosecutors worked closely with other institutional insiders within the federal government, particularly attorneys in the Office of the Inspector General within HHS. Because HHS helps to administer government health care programs through its Centers for Medicare and Medicaid Services (CMS), the agency served as a crucial partner for government prosecutors. In particular, prosecutors' legal settlements pertaining to AWP typically require the settling company to enter Corporate Integrity Agreements with HHS, which allow the agency to monitor the company's compliance with its new corporate responsibilities and grant it the authority to exclude non-compliant companies from government health care programs.

While prosecutors benefited from the assistance provided by institutional insiders within HHS to help enforce the new legal requirements they sought, the agency also benefited from these collaborations by gaining additional powers resulting from the prosecutors' settlements - powers that often went beyond the explicit authority established by Congress. For example, the TAP settlement not only granted the agency additional powers to oversee TAP's corporate operations, but it allowed CMS to rely upon the settlementgenerated ASP data in setting reimbursement rates for TAP's products under Medicare and Medicaid. This was despite Congress's previous enactment of the Medicare, Medicaid and SCHIP Benefits Improvement and Protection Act of 2000, which, among other things, precluded the agency from "directly or indirectly decreas[ing] the rates or reimbursement...under the current reimbursement methodology." This

Law \& Social Inquiry, Vol 40, No. 1 (Winter 2015): pg. 123-151. DOI. This article is C Wiley and permission has been granted for this version to appear in e-Publications@Marquette. Wiley does not grant permission for this article to be further copied/distributed or hosted elsewhere without the express permission from Wiley 
dynamic, in which government agencies assist prosecutors' mobilization of the law as a way to empower themselves, bears similarities to other ways in which agencies have supported the growth of the "litigation state" as a way to bolster bureaucratic capacity (Farhang 2010).

In addition to allying with institutional insiders, prosecutors also collaborated closely with outside groups. Among the most important collaborations were those between state-level public prosecutors and private plaintiffs' lawyers. As AWP litigation spread across the country, AGs hired private attorneys on a contingency fee basis to handle many of the states' tactical litigation decisions, including drafting legal briefs and crafting settlement provisions. Owing to the complexity of the AWP litigation, states drew from a common pool of private class action lawyers with particular expertise in pharmaceutical law. One plaintiffs' firm in particular, Hagens Berman, handled much of the day-to-day litigation for several of the states joining the campaign against drug companies. ${ }^{3}$ This coordination with a small pool of plaintiffs' lawyers had the effect of both harmonizing the "AWP-as-fraud" narrative and providing private attorneys with additional resources they could later use in private class-action litigation.

The initial federal and state prosecutions also served as a model for separate private class action lawsuits brought by advocacy groups with similar goals in mind. Pharmaceutical industry critics had long been active in the fight against high drug costs, but had focused their activism in legislative and regulatory avenues until the landmark Bayer and TAP settlements. These settlements opened up litigation as a promising new avenue for advocacy groups seeking reform of pharmaceutical pricing. In April 2001, a few months after the Bayer settlement, a coalition of various unions, non-profit health care organizations, and progressive advocacy groups formed the Prescription Access Litigation project (PAL). The coalition aimed to coordinate litigation with the purpose of "working to end illegal pharmaceutical industry practices and fighting for more affordable drug prices" (Prescription Access Litigation). Operating as a project of Community Catalyst, a national advocacy organization for consumer rights in the healthcare system, PAL was not hesitant to explain the policy-oriented purpose of their lawsuits:

The longer-term goal [of PAL's class action lawsuits] is to put a halt to drug company practices that keep the cost of drugs high.

Law \& Social Inquiry, Vol 40, No. 1 (Winter 2015): pg. 123-151. DOI. This article is (C) Wiley and permission has been granted for this version to appear in e-Publications@Marquette. Wiley does not grant permission for this article to be further copied/distributed or hosted elsewhere without the express permission from Wiley. 
The lawsuits will move the issue of access to prescription drugs to the forefront of the public eye. Historically, class action lawsuits have been a vehicle to encourage legislative leaders to take action on a particular policy issue. It is our hope that the actions of the PAL initiative will persuade state and Congressional legislative leaders to address the high price of prescription drugs and the problems many people experience in obtaining needed medications (Prescription Access Litigation).

In December 2001, two months after the announcement of the prosecutors' TAP settlement, the PAL coalition filed a major classaction lawsuit in Massachusetts against 28 drug companies. Most of the defendants in this lawsuit were already under investigation by federal and state prosecutors, which the class action complaint was quick to note. For each of the defendants, which included both TAP and Bayer, the complaint prominently stated that these companies had "been the target of government investigations" and included information drawn from these investigations as part of the narrative of criminal complicity that the complaint was attempting to build (Complaint, In Re Pharmaceutical Industry:39). The complaint also contained language similar to that in the prosecutors' earlier complaints, including characterizations of AWP as an "industry-wide scheme" to defraud those paying for prescription drugs (Complaint, In Re Pharmaceutical Industry: 1). The similarity of legal language was aided by the fact that many of the same private class-action firms that had been retained by AGs were also hired by members of the PAL coalition, which further coordinated tactics among the different elements of the anti-AWP coalition. ${ }^{4}$

In addition to targeting the same industry defendants as the government prosecutors, the goals of the litigation were very similar. Much as the prosecutors sought "nothing less than changing the way the industry does business" (Guiden 2001), the activist groups sought to use class-action litigation to force a "system change" in how the pharmaceutical industry sold their products (Gold and Caffrey 2002). Given this shared focus on similar public policy goals, it is not surprising that the lawsuits filed by the PAL coalition built directly upon the "AWP-as-fraud" frame developed by the government prosecutions. The similarities between the lawsuits brought by prosecutors and members of the PAL coalition resulted in several of the AGs' lawsuits being consolidated with PAL's in federal court (In Re Pharmaceutical 
Industry). AWP litigation continues to this day, and public and private plaintiffs have reached dozens of settlements with pharmaceutical company defendants.

\section{The Power of Prosecutors as a Coalition Leader}

As initiators of the AWP litigation, prosecutors led a broader coalition of cause lawyers that now includes agency lawyers, advocacy groups, and the private bar. As Austin Sarat and Stuart Scheingold have described them, cause lawyers share a commitment to "altering some aspect of the social, economic, and political status quo" (1998:4). Despite this broad formulation, studies of cause lawyering have shared an emphasis on "bottom-up" studies of legal mobilization by focusing on the actions of "outsider" lawyers, reflecting the view that "cause lawyering is everywhere a deviant strain within the legal profession" (Sarat \& Scheingold 1998:3). The NAACP's campaign against segregated education remains the classic example of cause lawyering, though studies have also examined cause lawyering for the poor, gays and lesbians, consumers, and evangelicals (Sarat \& Scheingold 2006). These studies situate cause lawyers as actors outside and opposed to the state who use legal processes to force changes to the political status quo. Law-based reform groups such as PAL, as an explicitly political "outsider" consumer advocacy group, appear to fit the typical model of cause lawyers well.

Government prosecutors are in some ways the consummate "insiders," since their typical role is to use the law to carry out the interests of the state. Nevertheless, the litigation campaigns described in this article suggest that prosecutors occupy a more complicated position in the legal community. Through innovative interpretations of ambiguous civil and criminal law, prosecutors have employed their legal resources as leverage to achieve political changes that other parts of the state have declined to make. In this way, they act as "insiders" within the state that are nevertheless positioned against the state. Despite their insider status, they seek very similar goals as the advocacy group allies with whom they frequently collaborate. Beyond providing "elite support" for these outsider groups, government prosecutors have taken a leadership role in litigation campaigns such as that against the pharmaceutical industry.

Law \& Social Inquiry, Vol 40, No. 1 (Winter 2015): pg. 123-151. DOI. This article is (C) Wiley and permission has been granted for this version to appear in e-Publications@Marquette. Wiley does not grant permission for this article to be further copied/distributed or hosted elsewhere without the express permission from Wiley. 
The characterization of government prosecutors as akin to "cause lawyers" is not to suggest that widespread change of the political status quo was their only motivation. After all, pharmaceutical industry settlements generated a great deal of money for the government, and many of the prosecutors involved, at least at the state level, were elected officials for whom electoral considerations undoubtedly loomed large. With that caveat in mind, however, the similarity between the explicit political reform goals of government prosecutors and outside activists is difficult to dismiss. While these goals likely mixed with other more self-interested motives, such motivational complexity is likely true of most cause lawyering. ${ }^{5}$ Although private class action litigators often argue that their litigation seeks justice for clients who would otherwise be without a voice, monetary considerations also influence whether these actors bring litigation. Likewise, the existence of various motivations for government attorneys to engage in legal mobilization ought not to obscure that a commitment to "altering some aspect of the social, economic, and political status quo" was a central concern for these prosecutors - a motivation recognized by the advocates who partnered with prosecutors to mobilize the law for political change.

Indeed, the government lawyers' position as advocates for the "public interest" offered them unique advantages as cause lawyers that helped them serve as a vanguard for a broader movement. For one, by suggesting that they were merely "enforcing the law" against rogue drug companies, government attorneys created what Eugene Lewis termed an "apolitical shield" around activities that are actually very much political (Lewis 1980:17-18). The apolitical shield possessed by law enforcers made it more difficult for pharmaceutical industry defendants to claim that the legal attack they faced was motivated by a group with an ideological axe to grind.

Prosecutors also brought significant institutional resources to this litigation. In Galanter's oft-cited terminology (1974), prosecutors are repeat players with advantages over private one-shotters who attempt to use litigation as an instrument of reform. Most importantly, prosecutors offer important elements of "standing" in two senses of the word. First, their position as advocates for the "public interest" provide them legal standing unavailable to private litigators, allowing them to access court by connecting allegations of pharmaceutical "fraud" to direct harm to their ostensible client, the American 
taxpayer. Second, they have standing in the sense of "having a voice in the media" (Ferree, et al. 2002, 86). As respected law enforcement personnel, prosecutors are better positioned to gain the attention and sympathies of the mass media. In an American society undergoing a broader turn to "governing through crime" (Simon 2008; McCann, Haltom \& Fisher 2013) and in which "popular entertainment celebrates such enforcers of criminal law" (McCann, Haltom \& Fisher 2013:12) government prosecutors are in a strong position to gain media standing unavailable to private litigators and thus exert meaningful pressure through their legal mobilization campaigns.

\section{Establishing New Legal Norms: The Broader Framing Effects of Litigation}

At the start of the prosecutors' AWP litigation campaign, legislative efforts to control the price of drugs faced significant constraints in part because they operated under frames that were unfavorable given the political context. Particularly after Republicans won control of Congress in the 1994 elections, the conservative congressional majority was unlikely to be moved by calls to "combat corporate greed" through price controls the industry viewed as an unwarranted intervention into the free market. Further, health care providers gave lawmakers a compelling frame of the AWP system as a necessary way to compensate them for losses they incurred providing other services under Medicare and Medicaid. These existing frames, bolstered by decades of AWP's persistence, appeared to provide a strong rationale for AWP's continued existence in the 1990s.

As law enforcement actors, prosecutors used their position to shift the frame surrounding these longstanding drug pricing practices. Throughout the litigation was an attempt to replace the positive frame of AWP as a necessary part of the Medicare and Medicaid system with a negative frame of AWP as "fraud" by lawbreaking pharmaceutical companies. It was no coincidence that prosecutors' legal complaints characterized the existing payment system as an "AWP Scheme" and part of a "racketeering enterprise." Prosecutors also employed the media to advance these negative frames following settlements by issuing coordinated press releases containing frames of corporate malfeasance. ${ }^{6}$ This strategy shares much in common with activists' efforts to criminalize Big Tobacco beginning in the 1990s (McCann,

Law \& Social Inquiry, Vol 40, No. 1 (Winter 2015): pg. 123-151. DOI. This article is @ Wiley and permission has been granted for this version to appear in e-Publications@Marquette. Wiley does not grant permission for this article to be further copied/distributed or hosted elsewhere without the express permission from Wiley. 
Haltom \& Fisher 2013). As with the tobacco litigation, litigation against pharmaceutical companies followed a "crimtort" model involving a hybrid of civil and criminal legal claims that was part of a broader effort to criminalize previously accepted corporate behavior (Koenig \& Rustad 1998; McCann, Haltom \& Fisher 2013).

A significant aspect of this re-framing of AWP as "fraud" is that it appealed across the political spectrum, which was particularly important in an era in which conservative Republicans were ascendant in various policy-making arenas. Many liberal critics of "Big Pharma" had little problem viewing the AWP system as another example of corporate greed within the drug industry. Yet this re-framing also appealed to conservatives who seized upon the AWP system as another example of waste, fraud, and abuse in burgeoning federal social programs. Republicans praised legislative efforts to encourage state AWP lawsuits against drug companies, for example, as a way to help U.S. taxpayers "recover the billions of dollars stolen through fraud every year" (151 Cong. 31 Oct. 2005:12069). As Senator John McCain (R-AZ) put it, pharmaceutical pricing "fraud" was another example of "wasteful and unnecessary" government spending (151 Cong. 20 Dec. 2005: 14073). Helping advance this anti-government "waste" frame was the fact that the coalition of prosecutors litigating against drug companies included a bipartisan group of Republican and Democratic AGs as well as George W. Bush's Department of Justice.

Prosecutors, at least those on the state level, were also able to draw upon their status as the legal representatives of their states in a way that provided them an advantageous position. Scholars have noted how the conservative shift in the courts beginning in the 1970s, which continued through the Supreme Court's "federalism revolution" in the 1990s, resulted in a judiciary more sympathetic to state-based legal claims. The courts' sympathies to "states' rights" helped state litigators find more success across a broad range of legal claims (Waltenburg \& Swinford 1999). By characterizing drug pricing reform as a crucial issue for the states, the AGs' legal mobilization was compatible with frames held in a positive light by judicial actors, thereby providing more plausibility to threats of litigation.

The prosecutors' framing contributed to shifts in the political landscape as Congress and the courts gradually accepted the new legal understanding of AWP advocated by government prosecutors. After years of refusing to change the AWP formula for drug reimbursements,

Law \& Social Inquiry, Vol 40, No. 1 (Winter 2015): pg. 123-151. DOI. This article is @ Wiley and permission has been granted for this version to appear in e-Publications@Marquette. Wiley does not grant permission for this article to be further copied/distributed or hosted elsewhere without the express permission from Wiley. 
Congress began shifting its posture following the success of the Bayer and TAP settlements and the wave of state litigation that followed. Building upon the existing federal and state investigations, an increasing number of members of Congress decided to respond with their own investigations (Pharmaceutical Law \& Industry Report 2003: 711). Indeed, key congressional committees sought and incorporated information from these lawsuits as part of their own investigations (Pharmaceutical Law \& Industry Report 2004b: 604). A few months after the Bayer settlement and in the midst of the TAP investigation and increasing state litigation, Congress held its first hearing to discuss problems with the AWP system. The very title of the hearing was revealing, as it characterized the AWP "a broken system for patients and taxpayers" despite only months earlier requiring the Medicare system to keep using the AWP benchmark and prohibiting any alternatives (107 Cong. 21 Sept. 2001). Following this first hearing in 2001, the number of congressional committees examining the issue proliferated. ${ }^{7}$ Congress invited prosecutors to testify about their lawsuits and explain how drug companies committed "fraud" in their state Medicaid programs (108 Cong. 7 Dec. 2004).

Following the TAP settlement in 2001, one industry attorney remarked, "Three or four years ago, if you surveyed manufacturers and asked if AWPs were kickbacks, they'd have looked at you like you were from another planet" (Carter 2002:44). By 2003, the terms of the debate had changed to such an extent that Congress reversed its decades-long support for AWP and began seeking alternatives for the system. In December 2003, Congress addressed the issue of prescription drug reimbursements in the Medicare Prescription Drug, Improvement, and Modernization Act (MMA). The MMA moved to end AWP as the baseline for reimbursement rates in the newly created Medicare Part D program as well as for prescription drugs already provided under the program. In the place of AWP, now described as a "flawed" system, Congress adopted precisely the same pricing benchmark developed as part of the TAP and Bayer settlements - the "Average Sales Price." The MMA borrowed the definition of ASP directly from the settlements, defining it as an average of the actual final sales prices of the drugs including all rebates and other discounts. Congress also required companies participating in the Medicare program to report the ASPs for their drugs to CMS on a quarterly basis, similar to the provisions previously achieved in the Bayer and TAP settlements.

Law \& Social Inquiry, Vol 40, No. 1 (Winter 2015): pg. 123-151. DOI. This article is (C) Wiley and permission has been granted for this version to appear in e-Publications@Marquette. Wiley does not grant permission for this article to be further copied/distributed or hosted elsewhere without the express permission from Wiley. 
NOT THE PUBLISHED VERSION; this is the author's final, peer-reviewed manuscript. The published version may be accessed by following the link in the citation at the bottom of the page.

In essence, these congressional changes were acquiescing to the national changes in pharmaceutical pricing that government prosecutors were already achieving, settlement by settlement, through their litigation.

\section{Law Enforcement as Legal Mobilization beyond the AWP Context}

As public policy and organizational scholars have long noted, organizations learn from their experiences (March and Olsen 1979; Baumgartner and Jones 2002). Positive feedback reinforces future activity, creating public policy cascades in which "each change begets another even larger change" (Jones and Baumgartner 2005, 139). Similarly, social movement scholars have noted how movement strategies often migrate from one setting to another as "the dissemination of ideas and models...cause actors to perceive new possibilities or imperatives for action" (Davis et al 2005:53; Minkoff 1997). The success of the NAACP's civil rights litigation in Brown $v$. Board of Education, for example, provided a signal to other social movement groups that the judiciary was willing to consider their claims, leading these groups to emulate the NAACP's legal strategies (Meyer \& Boutcher 2007). These notions of policy feedback effects and diffusion processes help to explain the development of mechanisms that might have been unusual and limited to one setting at one time but have since become commonplace across a variety of contexts.

These dynamics capture what has become an emerging model of government litigation that began with the tobacco litigation and has spread to several other policy contexts. Linking these campaigns is the coordinated efforts to force organizational reform through global settlements, expand the scope of the conflict with various other groups, and establish new legal norms in an effort to fundamentally shape the practices of entire national industries. This differs from the typical role of government attorneys as defending the policy status quo from law-based attempts to change it by outsider movements or to "enforcing the law" against individual law-breakers in a reactive, ad hoc fashion.

The lineage for this sort of legal mobilization traces to the previously mentioned tobacco litigation that settled just as the government's drug pricing investigations were beginning to unfold.

Law \& Social Inquiry, Vol 40, No. 1 (Winter 2015): pg. 123-151. DOI. This article is (C) Wiley and permission has been granted for this version to appear in e-Publications@Marquette. Wiley does not grant permission for this article to be further copied/distributed or hosted elsewhere without the express permission from Wiley. 
Like the pharmaceutical pricing settlements, the tobacco settlement was important not only because of the large amount of money involved, but also because it served to place various restrictions and requirements on the industry that anti-tobacco advocates had long sought from Congress. The successful resolution of the tobacco litigation illustrated a couple of crucial aspects that have helped lead to this emerging model of coordinated government-led legal mobilization. First, it illustrated the power of "law enforcement" in getting results that private litigation could not. Facing coordinated, high-profile investigations by law enforcers willing to label widespread industry practices as "fraudulent," companies would be willing to settle for massive fines and agree to new regulations. Second, this process introduced a powerful policy-making alternative to legislation. The MSA rose from the ashes of failed attempts to regulate the industry through congressional statute, mirroring many of the regulations that had never been more than proposals in Congress. In short, governmentled legal mobilization could be a powerful way of achieving policy changes even when efforts in other venues have failed. Below I provide three additional areas in which law enforcement as legal mobilization has been similarly prominent.

\section{Pharmaceutical Marketing}

For one, the ongoing drug pricing litigation campaign represents only a part of the broader government-led attack on pharmaceutical industry practices. One of the fastest growing areas of government litigation against the drug industry involves use of lawsuits and settlements to reshape drug marketing. Most importantly, prosecutors have used the False Claims Act and other federal and state statutes to limit the ability of drug firms to promote the "off label" use of their products. While federal law does not explicitly allow pharmaceutical firms to promote uses of their products beyond those approved by the Food and Drug Administration (FDA), Congress in the late 1990s enacted the Food and Drug Modernization Act making it legal for drug firms to provide doctors with "neutral information" about the off-label uses of their drugs, including peer-reviewed scientific studies. This controversial change was a blow to industry critics who argued that such deregulation of industry practices posed risks to public health and

Law \& Social Inquiry, Vol 40, No. 1 (Winter 2015): pg. 123-151. DOI. This article is (C) Wiley and permission has been granted for this version to appear in e-Publications@Marquette. Wiley does not grant permission for this article to be further copied/distributed or hosted elsewhere without the express permission from Wiley. 
threatened to subvert the entire system of FDA regulation (Radley, Finkelstein \& Stafford 2006).

Much as they did in the AWP context, prosecutors followed losses by industry critics in Congress by initiating a litigation campaign that attempted to force organizational change through lawsuits and settlements. The spark for this legal mobilization was an investigation of Pfizer's marketing of its epilepsy drug, Neurontin. Relying upon an innovative interpretation of the False Claims Act and state consumer protection statutes, prosecutors suggested that when Pfizer disseminated information to doctors about the off-label uses of the drug, it constituted illegal and "fraudulent" off-label marketing. Despite the untested nature of these claims, as well as the firm's insistence that the prosecutors were seeking to penalize truthful speech protected by the First Amendment, Pfizer agreed to a $\$ 430$ million settlement in May 2004. In addition to the fine, the settlement contained regulatory provisions and mechanisms of legalized accountability similar to those in the AWP settlements (Pharmaceutical Law \& Industry Report 2004a: 534).

The Neurontin settlement served as a way to expand the scope of the conflict by drawing in additional attacks on pharmaceutical industry marketing practices. Following the Neurontin settlement, AG and class action litigation alleging off-label marketing fraud proliferated. Litigation has continued to the present, with drug firms collectively paying billions in fines and agreeing to various new corporate requirements (Osborn 2013). As with the AWP case, prosecutors also worked closely with federal agency lawyers on these cases. A particularly important partner has been the Food and Drug Administration (FDA), which has seen its power to oversee pharmaceutical marketing increase because of the investigations (Pagano 2009).

The prosecutors' mobilization of the law against the prescription drug industry was also an attempt to establish new legal norms by "sending a message" that would resonate throughout the industry. While legal settlements in this and other contexts do not create formal legal precedents, they can prove invaluable in creating "business precedents" informally shaping the corporate landscape. The establishment of these business precedents led to the pharmaceutical industry's peak association adopting new voluntary guidelines, mirrored after recent settlements, aiming to help avoid liability for its 
NOT THE PUBLISHED VERSION; this is the author's final, peer-reviewed manuscript. The published version may be accessed by following the link in the citation at the bottom of the page.

members (Pharmaceutical Law \& Industry Report 2007: 16). Several individual companies also announced reforms to their advertising practices to help them avoid future liability (Arnold 2008).

\section{Gun Control}

Another prominent effort of government litigators to use lawsuits and settlements to reshape the political status quo, coming directly in the wake of the tobacco settlement of 1998, was in the area of gun control. In October of 1998, attorneys representing the city of New Orleans filed a complaint against several gun manufacturers alleging that they defectively designed their handguns because they lacked safeguards preventing gun use by children or criminals (Morial v. Smith \& Wesson Corp.). Shortly after, city attorneys for Chicago filed a lawsuit claiming that gun manufacturers had created a "public nuisance" by designing, manufacturing, marketing, and supplying their products in a way enabling a black market for illegal firearms within the Chicago city limits (Butterfield 1998).

These two city lawsuits opened a floodgate of subsequent lawsuits against the gun industry, with over thirty municipalities eventually filing suit (Violence Policy Center). Government attorneys beyond the local level soon after joined the litigation campaign. In 1999, Eliot Spitzer and Richard Blumenthal, the AGs of New York and Connecticut respectively, began investigations of several gun manufacturers. Andrew Cuomo, Clinton's Secretary of Housing and Urban Development (HUD), began working on a legal strategy mirroring many of the city lawsuits, alleging that gun manufacturers had not been properly supervising their distribution channels and had otherwise failed to promote gun safety (Walsh 1999). In December 1999, President Clinton and Secretary Cuomo jointly announced that they were planning a lawsuit against gun manufacturers on behalf of 3,200 public housing authorities across the country, based upon the notion that the actions of the gun manufacturers had increased federal expenditures (Stout \& Perez-Pena 1999).

The gun control litigation, like other recent nationwide litigation campaigns, aimed to force organizational change in the firearms industry. As New Orleans Mayor Marc Morial stated at the time: "money is not our primary aim. Changing the behavior and the practice of the gun industry is" (Koch 1999). Government prosecutors

Law \& Social Inquiry, Vol 40, No. 1 (Winter 2015): pg. 123-151. DOI. This article is @ Wiley and permission has been granted for this version to appear in e-Publications@Marquette. Wiley does not grant permission for this article to be further copied/distributed or hosted elsewhere without the express permission from Wiley. 
used a variety of coordinated legal strategies to achieve a settlement seeking legalized accountability and requiring "more stringent regulation in an effort to keep guns out of the wrong hands" (Barrett 2000). In March 2000, several of the public litigators reached a major settlement with Smith \& Wesson, the largest manufacturer of handguns in the industry. The settlement contained numerous provisions relating to firearms safety and design, as well as several concerning the company's sales, marketing, and distribution practices. It also contained several provisions aimed at ensuring compliance, including requirements that the company designate a compliance officer tasked with ensuring adherence with the terms of the agreement (Smith \& Wesson Settlement 2000:III(c)(1)-(3)).

Second, the public gun litigation served to expand the scope of the conflict in a context in which advocates for stricter gun control were losing in other venues. Particularly after Republicans won control of Congress in the 1994 elections, federal gun control legislation faced little prospects for success. This litigation campaign served as an alternative way to achieve gun control policies. Like other campaigns, this conflict featured similar alliances between government litigators and federal bureaucracies, with state and local litigators working closely with HUD to achieve what the Clinton Administration and other gun control advocates had failed to achieve through legislative channels. Further, several private class-action attorneys and interest groups, often working in conjunction with government litigators, also sought to use litigation to control the gun industry. The Brady Center to Prevent Handgun Violence, a leading pro-gun control interest group, joined most of the city lawsuits against the gun industry and assisted the State of New York in its gun industry litigation (Tyler 1999). The Castano Group, a coalition of dozens of private class-action law firms that had worked with AGs on the tobacco litigation, also worked closely with public prosecutors (ibid).

Finally, the gun litigation campaign was an attempt to establish new legal norms. Similar to what occurred in the tobacco litigation, the gun lawsuits framed industry actions as deceptive behavior that posed a threat to public health and budgets. This had some initial effects on the broader legal landscape. Prior to 1999, no private lawsuits had ever found a gun manufacturer liable for the criminal use of firearms. In February 1999, however, only a few months after the initial city lawsuits, a federal jury did just that. In Hamilton v. Accu-Tek, a jury in 
New York found 15 of the 25 manufacturers named in the suit liable under a "negligent marketing" theory, imposing damages on three of those companies. Several of the government lawsuits that went to trial following the Smith \& Wesson settlement achieved at least some initial successes as well (City of Cincinnati v. Beretta U.S.A. Corp. 2002).

Ultimately, however, this campaign failed to be the key turning point in the gun control debate as it initially appeared. A swift and overwhelmingly negative response from Smith \& Wesson's customer base and the National Rifle Association prompted Smith \& Wesson to back away from its agreement, and Congress enacted the Protection of Lawful Commerce in Arms Act of 2005 prohibiting most litigation against the gun industry. Despite its ultimate failure, however, this government-led litigation campaign illustrated a dynamic similar to other recent attempts to use government litigation to reshape corporate practices.

\section{Reform of Mortgage Lending Practices}

In 2000, AGs began investigating several mortgage lenders for allegedly engaging in "predatory lending" that targeted lower-income, elderly, and minority communities. These practices had long been the target of activists who had claimed that these loans acted as a financial trap for the most vulnerable citizens, turning the American dream into a nightmare. While only a few states specifically had antipredatory lending statutes on the books (Davenport 2003), state prosecutors suggested that practices in the subprime market might nevertheless violate the broad and vaguely worded prohibition of "unfair and deceptive acts" under general state consumer protection law.

Despite the uncertainty of whether the lenders' conduct was actually illegal under existing law, the government litigators used their combined threat of widespread legal liability to leverage major settlements with members of industry aimed at forcing organizational change. In 2002, the government coalition, now joined by all fifty states, reached a $\$ 484$ million settlement with mortgage giant Household Finance. The settlement required the company to adhere to several strict lending requirements, including limitations on prepayment penalties, new required consumer disclosures, and various other prohibitions and regulations. The settlement also sought 
legalized accountability by establishing an "independent monitor" to oversee Household's compliance with the settlement and requiring employee training to ensure compliance with the agreement (Household Finance Consent Judgment 2002:24-28). These requirements went beyond anything required by the federal government or most states, effectively nationalizing many of the regulations similar to those industry critics unsuccessfully sought through state and federal legislative channels. These early efforts served as the framework for later settlements with the largest national lenders, including a $\$ 325$ million settlement with Ameriquest and a landmark $\$ 8.68$ billion settlement with Countrywide Financial (Ameriquest Multistate Settlement 2006:36-39; Countrywide Stipulated Judgment and Injunction 2008:22). In February 2012, federal and state prosecutors reached a $\$ 26$ billion settlement with the nation's five largest mortgage servicers, which represented the largest single legal settlement since the tobacco settlement. The settlement, which sought to end "robo-signing" practices in the mortgage industry, continued the trend of requiring companies to adopt new training procedures and regulatory requirements to prevent activities not clearly illegal under existing law (National Foreclosure Consent Judgment 2012).

The government litigation campaign also helped to expand the scope of the conflict. State and federal prosecutors created new national committees and working groups focused on lending issues throughout the 2000s, which served as a coordination mechanism not only for prosecutors but for numerous other interests as well. The Financial Fraud Enforcement Task Force created in 2009, for example, has served as a centralized entity coordinating enforcement efforts, training programs, and fraud data collection among numerous government agencies, consumer groups, legal aid attorneys, and others (Financial Fraud Enforcement Task Force 2010). Additionally, private class-action litigation alleging lending abuses has used investigations by state litigators as part of building a narrative of criminal complicity, similar to the pharmaceutical litigation (Ameriquest Settlement Agreement 2009:4-5).

Finally, the campaign has also helped to establish new legal norms concerning what constitutes "predatory lending." The legislative debate about bank regulation had proceeded along polarized frames of consumer welfare versus government interference with the free

Law \& Social Inquiry, Vol 40, No. 1 (Winter 2015): pg. 123-151. DOI. This article is @ Wiley and permission has been granted for this version to appear in e-Publications@Marquette. Wiley does not grant permission for this article to be further copied/distributed or hosted elsewhere without the express permission from Wiley. 
market. Government prosecutors sought to re-frame the regulations achieved through settlements as necessary to "enforce the law" against lawbreaking corporate giants, which, as with reconceptualizing existing business practices as "fraudulent" in the pharmaceutical context, was a more acceptable way to achieve expanded government regulation than the existing polarized debate. The ambiguity of "predatory lending" granted government prosecutors the chance to shape its meaning through mobilizing the law against leading firms in the lending industry. The changing legal environment helped bolster legislative efforts to address lending practices. For example, California enacted a "Homeowner Bill of Rights" that incorporated and built upon the provisions in the government prosecutors' mortgage industry settlement in February 2012. This legislation applies the settlement's provisions to banks and other lenders not party to the original settlement (Lifsher \& Lazo 2012). Additionally, recent congressional statutes and regulations targeting mortgage lending practices codified elements of previous settlements as a way of setting a federal floor for regulatory practices (Reckard 2013).

\section{Conclusion}

Government litigation campaigns have proliferated in recent years and present several themes of interest to scholars of law and politics. These campaigns illustrate that legal mobilization is not only a way for political outsiders to challenge the state, but also serves as a powerful policy-making tool used by actors inside the state. Far from simply "enforcing the law," prosecutors have employed the instrumental and constitutive power of the law to force changes in organizational practices, expand the scope of the conflict over corporate responsibilities, and reshape existing legal norms through lawsuits and settlements. These activities illustrate how attention to legal processes unfolding across multiple political institutions can provide a more comprehensive understanding of the role of law in social and political change.

Further, the prevalence of government-led legal mobilization shows few signs of abating. Reflecting several parallel trends in American politics, private reform groups have increasingly collaborated with public litigators to mobilize the law. Intensifying political 
polarization and congressional gridlock have made traditional policy making more difficult, leading advocates to seek policy change in other venues. At the same time, however, private litigators have found it increasingly difficult to access the legal system as Congress and the Supreme Court have curtailed opportunities for private litigators to sue corporations.

In this political environment, prosecutors are a promising avenue for challenges to the status quo. As repeat players tasked with representing the "public interest," these institutional insiders maintain privileged access to the courts. Further, by couching widespread political changes in the apolitical language of law enforcement, prosecutors have gained support from across the 1 The following analysis of the Average Wholesale Price (AWP) case relies heavily upon the author's cataloguing of government lawsuits and settlements targeting the pharmaceutical industry. The main resource used for compiling this information was the Lexis-Nexis "United States News Verdicts, Settlements \& Decisions" database. For each year from 1980 to 2012, the following search string was used: [("average wholesale price" or AWP or ((drug! or pharmaceutical!) w/2 pric!)) and (litigation or "settlement \& compromise" or "suits \& claims" or verdicts or "decisions \& rulings" or "consent decrees \& orders" or investigations)]. Additional information about AWP litigation was collected as political system for changes that would otherwise be controversial. Given their shared goals of political change, increasingly disadvantaged private litigators have compelling reasons to ally with their powerful public counterparts.

All of this suggests that scholars have much to gain by granting greater attention to the role of government law enforcement in the process of legal mobilization. While legal actions targeting corporate "fraud" may initially appear to have little to do with politics, especially since they are rarely resolved by high profile Supreme Court decisions, politics are in fact a central part of the story. Given the roadblocks to policy reform currently existing in the contemporary American political system, this form of legal mobilization has proven to be an increasingly important avenue for achieving widespread change through the law.

Law \& Social Inquiry, Vol 40, No. 1 (Winter 2015): pg. 123-151. DOI. This article is (C) Wiley and permission has been granted for this version to appear in e-Publications@Marquette. Wiley does not grant permission for this article to be further copied/distributed or hosted elsewhere without the express permission from Wiley. 
NOT THE PUBLISHED VERSION; this is the author's final, peer-reviewed manuscript. The published version may be accessed by following the link in the citation at the bottom of the page.

\section{Notes:}

1 The following analysis of the Average Wholesale Price (AWP) case relies heavily upon the author's cataloguing of government lawsuits and settlements targeting the pharmaceutical industry. The main resource used for compiling this information was the Lexis-Nexis "United States News Verdicts, Settlements \& Decisions" database. For each year from 1980 to 2012, the following search string was used: [("average wholesale price" or AWP or ((drug! or pharmaceutical!) w/2 pric!)) and (litigation or "settlement \& compromise" or "suits \& claims" or verdicts or "decisions \& rulings" or "consent decrees \& orders" or investigations)]. Additional information about AWP litigation was collected as described in footnote 2 below. Following these searches, the author obtained settlement documents for each of the cases from the Web sites of individual AG offices as well as the federal DOJ and HHS.

2 The information regarding states' AWP litigation in Table 1 was collected from a search of the Web sites of each of the fifty states' Attorney General offices, which typically contain a listing of legal complaints filed and/or press releases concerning new litigation. This search was supplemented with a search of the "All News" database within LexisNexis, starting with the terms "Average Wholesale Price" and "Alabama" and subsequently continuing through all fifty states.

${ }^{3} \mathrm{~A}$ listing of the various cases the Hagens Berman law firm has been involved in is available on the firm's Web site, http://www.hbsslaw.com/casesand-investigations (accessed February 26, 2014).

${ }^{4}$ According to PAL's Web site, this includes Hagens Berman, the same plaintiffs' firm that has worked closely with AGs on several AWP cases (Prescription Access Litigation).

${ }^{5}$ Contained within the NAACP's broader law-based fight for racial justice was, for example, a contest between civil rights pioneers Thurgood Marshall and Carter Wesley for leadership in the black community (Tushnet 2005).

${ }^{6}$ A press release issued by Louisiana's AG following a 2012 AWP settlement with several drug companies provides a typical example: "I will, as Attorney General, continue to aggressively pursue pharmaceutical companies who defraud our Medicaid program. We are sending a message to drug companies that their fraud will not be tolerated in Louisiana" (Office of the Attorney General of Louisiana 2012).

7 Problems with AWP have been mentioned at least in passing in dozens of congressional hearings beginning in 2001, with major hearings discussing AWP at length occurring nearly every year since.

Law \& Social Inquiry, Vol 40, No. 1 (Winter 2015): pg. 123-151. DOI. This article is @ Wiley and permission has been granted for this version to appear in e-Publications@Marquette. Wiley does not grant permission for this article to be further copied/distributed or hosted elsewhere without the express permission from Wiley. 
NOT THE PUBLISHED VERSION; this is the author's final, peer-reviewed manuscript. The published version may be accessed by following the link in the citation at the bottom of the page.

\section{Articles and Books Cited}

Albiston, Catherine. 1999. The Rule of Law and the Litigation Process: The Paradox of Losing by Winning. Law \& Society Rev. 33 (4): 869-910. Alpert, Bill. 1997. A Drug Bust in the Making? Barron's, October 27, 14. Appleby, Julie. 2000. Drug Companies Face Accusations about Pricing. USA Today, September 8, B3.

Arnold, Matthew. 2008. Four Agree to Moratorium. Medical Marketing \& Media 43: 24.

Barnes, Jeb. 2007. Bringing the Courts Back In: Interbranch Perspectives on the Role of Courts in American Politics and Policymaking. Annual Rev. of Political Science 10: 25-43.

Barnes, Jeb and Thomas Burke. (2012). Making Way: Legal Mobilization, Organizational Response, and Wheelchair Access. Law \& Society Rev. 46 (1): 167-198.

Barrett, Paul M. 2000. Gun Retailers Form Group to Push Views. Wall Street Journal, January 6, A4.

Baumgartner, Frank R. and Bryan D. Jones. 2002. Policy Dynamics. Chicago: University of Chicago Press.

Berenson, Steven K. 2009. Government Lawyer as Cause Lawyer: A Study of Three High Profile Government Lawsuits. Denver University Law Review 86 (2): 457-508.

Binder, Amy J. 2002. Contentious Curricula. Princeton, NJ: Princeton University Press.

Butterfield, Fox. 1998. Chicago is Suing Over Guns From Suburbs. New York Times, November 13, A18.

Carter, Terry. 2002. Drug Wars. ABA Journal 88: 41-45.

Cloud David S. and Laurie McGinley. 2000. U.S., States, Bayer Start Settlement Talks. Wall Street Journal, May 10, A3.

Community Catalyst. n.d.. Mission \& Values, http://www.communitycatalyst.org/about/mission-values (accessed February 26, 2014).

Cutler, Joyce E. 2003. AGs Targeting Pricing, Antitrust Issues In Pharmaceutical Industry, Official Says. Pharmaceutical Law \& Industry Report, October 3, 1062.

Danzon, Patricia M. and Michael F. Furukawa. 2008. International Prices and Availability of Pharmaceuticals in 2005. Health Affairs 27 (1): 221-233.

Davenport, Tania. 2003. An American Nightmare: Predatory Lending in the Subprime Home Mortgage Industry. Suffolk University Law Review 36: 531-557.

Davis, Gerald F, Doug McAdam, W. Richard Scott, and Mayer N. Zald, eds. 2005. Social Movements and Organization Theory. New York: Cambridge University Press.

Law \& Social Inquiry, Vol 40, No. 1 (Winter 2015): pg. 123-151. DOI. This article is @ Wiley and permission has been granted for this version to appear in e-Publications@Marquette. Wiley does not grant permission for this article to be further copied/distributed or hosted elsewhere without the express permission from Wiley. 
NOT THE PUBLISHED VERSION; this is the author's final, peer-reviewed manuscript. The published version may be accessed by following the link in the citation at the bottom of the page.

Department of Justice. 2001. TAP Pharmaceutical Products Inc. and Seven Others Charged with Health Care Crimes, http://www.justice.gov/opa/pr/2001/October/513civ.htm (accessed February 26, 2014).

Derthick, Martha A. 2001. Up in Smoke. Washington: CQ Press.

Elfin, Dana A. 2002. Nevada Sues Drug Companies to Recover Millions of Dollars in Alleged Overpayments. Pharmaceutical Law \& Industry Report, January 24.

Epp, Charles. 1998. The Rights Revolution. Chicago: University of Chicago Press.

------. 2009. Making Rights Real. Chicago: University of Chicago Press.

Ewick, Patricia and Susan S. Silbey. 1998. The Common Place of Law. Chicago: University of Chicago Press.

Farhang, Sean. 2010. The Litigation State. Princeton, N.J.: Princeton University Press.

Ferree, Myra Marx, William Anthony Gamson, Jürgen Gerhards, and Dieter Rucht. 2002. Shaping Abortion Discourse. New York: Cambridge University Press.

Financial Fraud Enforcement Task Force. 2010. First Year Report, http://www.stopfraud.gov/docs/FFETF-Report-LR.pdf (accessed February 26, 2014).

Freudenheim, Milt. 1993. Drug Companies Feeling Pressure of Clinton's Plan to Keep Their Prices Down. New York Times, September 30, A22.

Galanter, Marc. 1974. Why the 'Haves' Come Out Ahead: Speculations on the Limits of Legal Change. Law \& Society Review 9 (1): 95-160.

Gatyas, Gary. 2011. IMS Institute Reports U.S. Spending on Medicines Grew 2.3 Percent in 2010 , to $\$ 307.4$ Billion, http://www.imshealth.com/portal/site/ims/menuitem.d248e29c86589c 9c30e81c033208c22a/?vgnextoid =24b2f14cddc40310VgnVCM 100000 71812ca2RCRD\&vgnextfmt=default (accessed February 26, 2014).

Gencarelli, Dawn M. 2002. Average Wholesale Price for Prescription Drugs: Is There a More Appropriate Pricing Mechanism? National Health Policy Forum, Issue Brief No. 775, June 7, http://www.nhpf.org/library/issuebriefs/ib775_awp_6-7-02.pdf (accessed February 26, 2014).

Gold, Russell and Andrew Caffrey. 2002. States Suing Drug Makers Spurn Former Allies on Tobacco. Wall Street Journal, May 29, B1.

Guiden, Mary. 2001. States Mull Suit Against Drug Companies. Stateline, April 2, http://www. pewstates.org/projects/stateline/headlines/specialreport-states-mull-suit-against-drug-companies-85899393051 (accessed February 26, 2014).

Jones, Bryan D. and Frank R. Baumgartner. 2005. The Politics of Attention. Chicago: University of Chicago Press.

Law \& Social Inquiry, Vol 40, No. 1 (Winter 2015): pg. 123-151. DOI. This article is @ Wiley and permission has been granted for this version to appear in e-Publications@Marquette. Wiley does not grant permission for this article to be further copied/distributed or hosted elsewhere without the express permission from Wiley. 
NOT THE PUBLISHED VERSION; this is the author's final, peer-reviewed manuscript. The published version may be

accessed by following the link in the citation at the bottom of the page.

Kaiser Family Foundation. 2012. Health Care Costs: Key Information on Health Care Costs and Their Impact.

http://kaiserfamilyfoundation.files.wordpress.com/2013/01/767003.pdf (accessed February 26, 2014).

Kalb, Paul E., I. Scott Bass, and Robert Fabrikant. 2001. The Average Wholesale Price: It "Ain't What the Government Wants to Pay." Health Care Fraud Report, February 21, 182.

Katzenstein, Mary. 1998. Faithful and Fearless. Princeton: Princeton University Press.

Koch, Kathleen. 1999. Gun Litigation Follows Example of Tobacco Cases. June 6, http://edition.cnn.com/US/9906/06/guns.tobacco/ (accessed February 26, 2014).

Koenig, Thomas H. and Michael L. Rustad. 1998. 'Crimtorts' as Corporate Just Deserts. University of Michigan Journal of Law Reform 31: 289-352.

Krause, Joan H. 2004. A Conceptual Model of Health Care Fraud Enforcement. Journal of Law and Policy 12: 55-147.

Lewis, Eugene. 1980. Public Entrepreneurship. Bloomington, IN: Indiana University Press.

Lifsher, Marc and Alejandro Lazo. 2012. State OKs Mortgage Protections. Los Angeles Times, July 3, A1.

March, James G. and Johan P. Olsen, eds. 1979. Ambiguity and Choice in Organizations. Bergen, Norway: Universitetsforlaget.

Mather, Lynn. 1998. Theorizing about Trial Courts: Lawyers, Policymaking, and Tobacco Litigation. Law \& Social Inquiry 23 (4): 897-940.

McCann, Michael. 1994. Rights at Work. Chicago: University of Chicago Press.

------. 2006. Law and Social Movements. Annual Review of Political Science 2: 17-38.

------. 2008. Litigation and Legal Mobilization. In The Oxford Handbook of Law and Politics, ed. Keith E. Whittington, R. Daniel Kelemen, and Gregory A. Caldeira, 522-540. New York: Oxford University Press.

McCann, Michael, William Haltom, and Shauna Fisher. 2013. Criminalizing Big Tobacco: Legal Mobilization and the Politics of Responsibility for Health Risks in the United States. Law and Social Inquiry 38 (2): 288-321.

Meyer, David S. and Steven A. Boutcher. 2007. Signals and Spillover: Brown v. Board of Education and Other Social Movements. Perspectives on Politics 5 (1): 81-93.

Minkoff, Debra C. 1997. The Sequencing of Social Movements. American Sociological Review 62: 779-799.

Mnookin, Robert H. and Lewis Kornhauser. 1979. Bargaining in the Shadow of the Law: The Case of Divorce. Yale Law Review 88 (5): 950-997.

NeJaime, Douglas. 2012. Cause Lawyers Inside the State. Fordham Law Review 81 (2): 649-704.

Law \& Social Inquiry, Vol 40, No. 1 (Winter 2015): pg. 123-151. DOI. This article is @ Wiley and permission has been granted for this version to appear in e-Publications@Marquette. Wiley does not grant permission for this article to be further copied/distributed or hosted elsewhere without the express permission from Wiley. 
Office of the Attorney General of Louisiana. 2012. Attorney General Recovers $\$ 38$ Million from Drug Companies Charged with Fraud. July 25, http://www.ag.state.la.us/Article.aspx?articleID=611\&catID =2 (accessed February 26, 2014).

Osborn, John. 2013. Feds Have Beaten Pharma Into Submission Over OffLabel Drug Costs, But at What Cost? Forbes, November 7, http://www.forbes.com/sites/johnosborn/2013/11/07/ho-humanother-multi-billion-dollar-drug-company-fraud-settlement/ (accessed February 26, 2014.

Pagano, Susanne. 2009. Merck, Schering-Plough Settle With States Over Vytorin Study Release. Pharmaceutical Law \& Industry Report, July 17, 821.

Paris, Michael. 2010. Framing Equal Opportunity. Stanford, CA: Stanford University Press.

Pear, Robert. 2001. Bayer to Pay $\$ 14$ Million to Settle Charges of Causing Inflated Medicaid Claims. New York Times, January 24, A16.

-----. 2002. AARP Wants Bigger Role in Prescription Drug Cases. New York Times, April 23, A14.

Pharmaceutical Law \& Industry Report. 2001. TAP Settlement Redefining Marketing, Relationships Between Drug Firms, Doctors. Pharmaceutical Law \& Industry Report, December 13.

------. 2003. House Committee Questions Drugmakers In Expanded Medicaid Fraud Investigation. Pharmaceutical Law \& Industry Report, July 4.

------. 2004a. Pfizer Unit Pays \$430 Million to Settle Neurontin Off-Label, Medicaid Claims. Pharmaceutical Law \& Industry Report, May 14.

------. 2004b. Grassley Asks DOJ for Confidential Information From Medicaid Investigations. Pharmaceutical Law \& Industry Report, May 28.

------. 2007. International Pharma Trade Group Adopts New Code Barring Some Marketing Activities. Pharmaceutical Law \& Industry Report, January 5.

Prescription Access Litigation. n.d. PAL Coalition. http://web.archive.org/web/20130430105917/http://www.prescription access.org/lawsuitssettlements?id=0005 (accessed February 26, 2014).

Radley, David C., Stan N. Finkelstein, and Randall S. Stafford. 2006. Off-Label Prescribing Among Office-Based Physicians. Archives of Internal Medicine 166 (9): 1021-1026.

Raeburn, Nicole C. 2004. Changing Corporate America from the Inside Out. Minneapolis: University of Minnesota Press.

Reckard, E. Scott. 2013. New U.S. Rules for Lenders; Agency to Require Mortgage Servicers to Offer All Options to Keep People in Homes. Los Angeles Times, January 16, B1.

Law \& Social Inquiry, Vol 40, No. 1 (Winter 2015): pg. 123-151. DOI. This article is @ Wiley and permission has been granted for this version to appear in e-Publications@Marquette. Wiley does not grant permission for this article to be further copied/distributed or hosted elsewhere without the express permission from Wiley. 
NOT THE PUBLISHED VERSION; this is the author's final, peer-reviewed manuscript. The published version may be accessed by following the link in the citation at the bottom of the page.

Rosenberg, Gerald. 1991, 2008. The Hollow Hope. Chicago: University of Chicago Press.

Rovner, Julie. 1992. Prescription Drug Prices. CQ Researcher, July 17, 597616.

Sarat, Austin and Thomas R. Kearns, eds. 1993. Law in Everyday Life. Ann Arbor: University of Michigan Press.

Sarat, Austin and Stuart Scheingold. 1998. Cause Lawyering. New York: Oxford University Press.

-----. 2006. Cause Lawyers and Social Movements. Stanford, CA: Stanford University Press.

Schattschneider, E.E. 1960. The Semi-Sovereign People. New York: Holt, Rinehart, and Winston.

Simon, Jonathan. 2008. Governing through Crime. New York: Oxford University Press.

Sinclair, Barbara. 2011. Unorthodox Lawmaking, 4th ed. Washington D.C.: CQ Press.

Spears, James M. and Jeff Pullman. 2002. Using Litigation to Regulate Drug Prices: The Assault. Medical Marketing and Media, June, 70-76.

Stout, David and Richard Perez-Pena. 1999. Housing Agencies to Sue Gun Makers. New York Times, December 8, A1.

Tushnet, Mark. 2005. The NAACP's Legal Strategy Against Segregated Education, 1925-1950, 2nd ed. Chapel Hill: University of North Carolina Press.

Tyler, Patrick E. 1999. Tobacco-Busting Lawyers on New Gold-Dusted Trails. New York Times, March 10, A1.

Violence Policy Center. n.d. Litigation Against the Gun Industry. http://www.vpc.org/litigate.htm (accessed February 26, 2014).

Walsh, Sharon. 1999. Gunmakers Up in Arms Over HUD Plan to Sue Them. Washington Post, December 9, A2.

Waltenburg, Eric N. and Bill Swinford. 1999. Litigating Federalism. Westport, CT: Greenwood Press.

Zalesky, Christopher D. 2006. Pharmaceutical Marketing Practices: Balancing Public Health and Law Enforcement Interests. Journal of Health Law 39 (2): 235-264.

Zemans, Frances K. 1983. Legal Mobilization: The Neglected Role of the Law in the Political System. American Political Science Review 77 (3): 690703. 
NOT THE PUBLISHED VERSION; this is the author's final, peer-reviewed manuscript. The published version may be accessed by following the link in the citation at the bottom of the page.

\section{Cases and Legal Documents Cited}

Ameriquest Multistate Settlement Agreement. 2006. Signed January 23, http://www.ameriquestmultistatesettlement.com/pdfs/SettlementAgre ement.pdf (accessed February 26, 2014).

Ameriquest Settlement Agreement. 2009. In Re Ameriquest Mortgage Co. Mortgage Lending Practices Litigation, MDL No. 1715, signed December 4, https://ameriquestmdlsettlement.com (Site no longer active, document available from author).

AT\&T Mobility v. Concepcion, 563 U.S. (2011).

Bayer Corporate Integrity Agreement. 2001. Signed January 23, http://www.oig.hhs.gov/fraud/cia/agreements/BayerCorporation 12030 1.PDF (accessed February 26, 2014).

City of Cincinnati v. Beretta U.S.A. Corp., 768 N.E.2d 1136 (Ohio 2002).

Complaint, In Re Pharmaceutical Industry Average Wholesale Price Litigation. 2004. M.D.L. No. 1456, filed February 24 (document available from author).

Countrywide Stipulated Judgment and Injunction. 2008. Signed October 20, http://ag.ca.gov/cms_attachments/press/pdfs/n1618_cw_judgment.p df (accessed February 26, 2014).

Hamilton v. Accu-Tek, 62 F.Supp. 2d 802 (E.D.N.Y. 1999).

Household Finance Consent Judgment. 2002. Signed December 11, http://www.state.ia.us/government/ag/latest_news/releases/dec_200 2/hhconsent.pdf (accessed February 26, 2014).

In Re Pharmaceutical Industry Average Wholesale Price Litigation, M.D.L. No. 1456 (D. Mass, June 21, 2007).

Morial v. Smith \& Wesson Corp., No. 98-18578 (La. Civ. Dist. Ct., Orleans Parish) (filed, Oct. 30, 1998).

National Foreclosure Consent Judgment. 2012. Filed April 4, http://www.nationalmortgagesettlement.com (accessed February 26, 2014).

Smith \& Wesson Settlement. 2000. Signed March 17, http://www.nraila.org/news-issues/fact-sheets/2000/smith-wessonsettlement-agreement.aspx (accessed February 26, 2014).

TAP Corporate Integrity Agreement. 2001. Signed September 28, https://oig.hhs.gov/fraud/cia/agreements/tap_pharmaceutical_product s_92801.pdf (accessed February 26, 2014).

Wal-Mart v. Dukes, 564 U.S. _ (2011). 
NOT THE PUBLISHED VERSION; this is the author's final, peer-reviewed manuscript. The published version may be accessed by following the link in the citation at the bottom of the page.

\section{Statutes and Congressional Hearings Cited}

Balanced Budget Act of 1997, Public Law 105-33, 11 Stat. 251.

Class Action Fairness Act of 2005, Public Law 109-2, 199 Stat. 4.

Food and Drug Modernization Act of 1997, Public Law 105-115, 111 Stat. 2330.

International Prescription Drug Parity Act of 1999, H.R. 1885, 106th Cong. (introduced May 20).

Medicaid Prescription Drug Reimbursement: Why the Government Pays Too Much. 2004. Joint Hearing Before the Subcommittee on Oversight and Investigations of the House Committee on Energy and Commerce, 108th Cong., December 7.

Medicare Drug Reimbursements: A Broken System for Patients and

Taxpayers, 2001. Joint Hearing Before the Subcommittee on Health and the Subcommittee on Oversight and Investigations, 107th Cong. 65, September 21.

Medicare, Medicaid and SCHIP Benefits Improvement and Protection Act of 2000, Public Law 106-554.

Medicare Prescription Drug, Improvement, and Modernization Act of 2003, Public Law 108-173, 94 Stat. 2647.

Medication Price Control Act of 1991, H.R. 3823, 102nd Cong. (introduced November 19).

Prescription Drug Cost Containment Act of 1992, H.R. 4490, 102nd Cong. (introduced March 18).

Protection of Lawful Commerce in Arms Act of 2005, Public Law 109-92. 
NOT THE PUBLISHED VERSION; this is the author's final, peer-reviewed manuscript. The published version may be accessed by following the link in the citation at the bottom of the page.

Table 1: The Progression of State AWP Lawsuits

\begin{tabular}{|c|c|c|}
\hline State & Date Filed & Defendants \\
\hline Texas & September 2000 & Dey Laboratories, Schering-Plough, and Roxane \\
\hline West Virginia & October 2001 & Schering-Plough and Abbott Labs \\
\hline Nevada & January 2002 & 12 defendants \\
\hline Montana & February 2002 & 18 defendants \\
\hline Minnesota & June 2002 & Pharmacia \\
\hline New York & February 2003 & Pharmacia and GlaxoSmithKline \\
\hline Connecticut & March 2003 & 7 defendants \\
\hline Florida & July 2003 & 3 defendants \\
\hline Kentucky & September 2003 & 5 defendants \\
\hline Massachusetts & September 2003 & 13 defendants \\
\hline Arkansas & January 2004 & 4 defendants \\
\hline Ohio & March 2004 & 5 defendants \\
\hline Pennsylvania & March 2004 & 13 defendants \\
\hline Wisconsin & June 2004 & 20 defendants \\
\hline Alabama & January 2005 & 73 defendants \\
\hline Illinois & February 2005 & 48 defendants \\
\hline Missouri & May 2005 & Dey and Warrick \\
\hline California & August 2005 & 39 defendants \\
\hline Mississippi & October 2005 & 86 defendants \\
\hline Arizona & December 2005 & 42 defendants \\
\hline Hawaii & April 2006 & 44 defendants \\
\hline South Carolina & August 2006 & 5 defendants \\
\hline Idaho & June 2007 & 10 defendants \\
\hline Utah & September 2007 & 10 defendants \\
\hline Iowa & October 2007 & 78 defendants \\
\hline Kansas & November 2008 & 17 defendants \\
\hline Louisiana & November 2010 & 18 defendants \\
\hline
\end{tabular}


NOT THE PUBLISHED VERSION; this is the author's final, peer-reviewed manuscript. The published version may be accessed by following the link in the citation at the bottom of the page.

\section{Figure 1:}

\section{The Role of AWP in Government Prescription Drug Reimbursements}

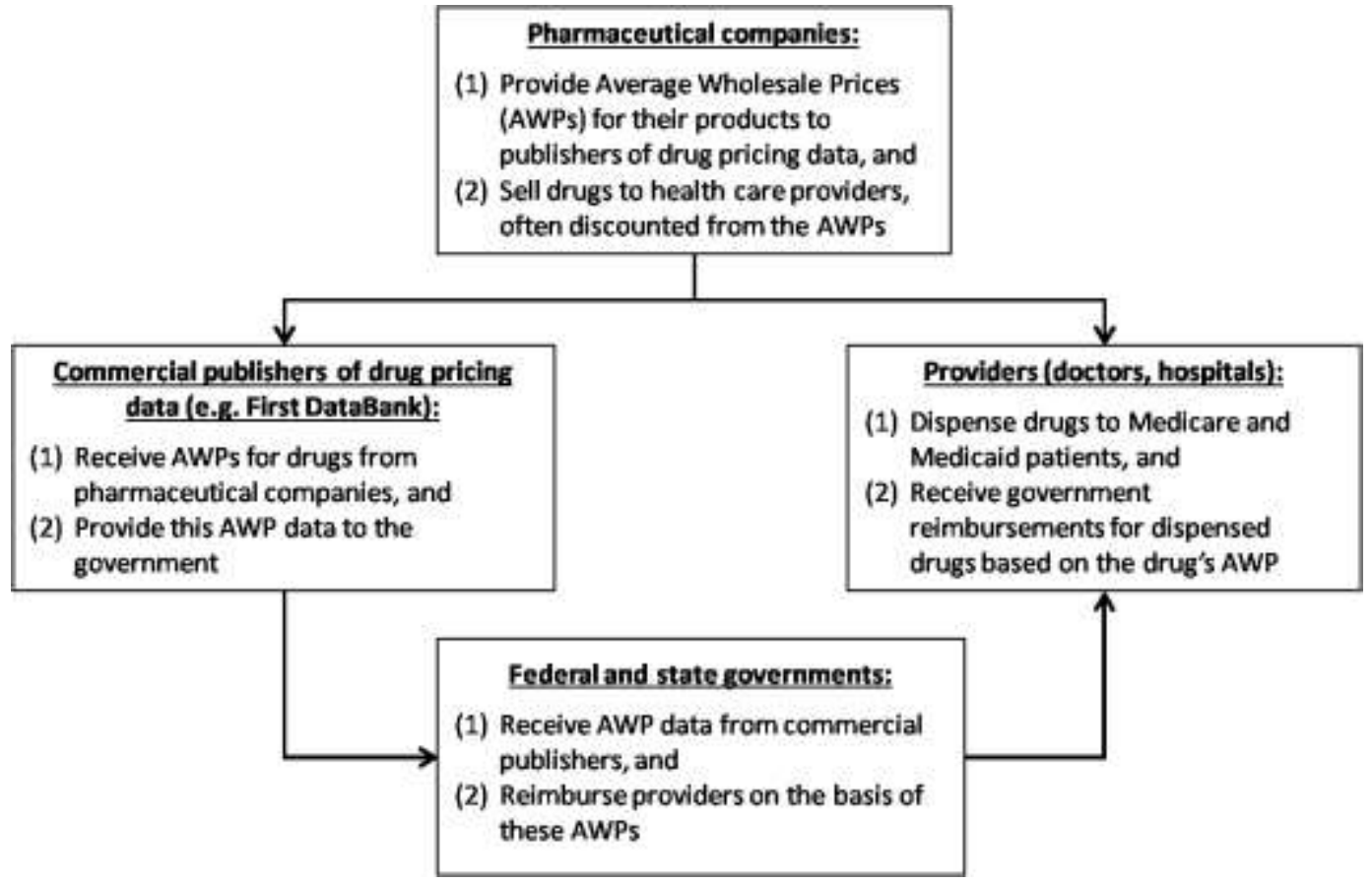

\section{About the author:}

Dr. Paul Nolette is an Assistant Professor of Political Science at Marquette University. His e-mail address is paul.nolette@marquette.edu. He would like to thank Julia Azari, Amber Wichowsky, Catherine Albiston, and three anonymous reviewers for their helpful comments and suggestions on earlier drafts of this article. Thanks as well to Shannon McLean and Mashal Amjad for their additional research assistance.

Department of Political Science, Marquette University Wehr Physics Building, Room 468 P.O. Box 1881 Milwaukee, WI 53201-1881

paul.nolette@marquette.edu

(414)288-5821 (telephone)

(414) 288-3360 (fax) 